\title{
PENGARUH BERAT BADAN TIDAK NAIK TERHADAP PERTUMBUHAN PADA BAYI 6-12 BULAN DI KABUPATEN BOGOR
}

\author{
Minarto $^{1}$ \\ ${ }^{1}$ Direktorat Gizi Masyarakat, Departemen Kesehatan RI
}

\begin{abstract}
The objective of the study is to examine the effect of not gaining weight on growth achievement and to identify its risk factors. The design of the study is a prospective cohort. Some 2196 -month old infants met sample inclusion criteria at enrollment (did not suffer from chronic diseases, had normal nutritional status, and the parents willing to involve in the study). The data collected include weight and length, morbidity, food consumption and child care practices, and socio-economic status of the family. The weight of infant was measured using SECA digital scale, and length was measured using standardized length board. Precision and accuracy test was carried out based on WHO procedure. The study found that the frequency and consecutive events of not gaining weight have a significant effect on weight achievement at 12 months of age. The differences of weight increment from 6 to 12 months between infants who did not experience growth failure and those who did not gain weight 1 time, 2 times, and 3 times were 200 grams, 450 grams and 1150 grams respectively. The frequency and consecutiveness of not gaining weight was associated with food consumption patterns and morbidity status of infants. Further analysis showed that infants suffered from coughing $>14$ days had risk ratio of 2.2 times $(95 \% \mathrm{Cl} 1.197-3.930)$ higher having 2 times not gaining weight than those who suffered $\leq 14$ days. While, infants suffered from coughing $>28$ days had a risk ratio of 5 times $(95 \% \mathrm{Cl} 1.472-15.678)$ higher having 3 times not gaining weight than those who suffered $<=28$ days. There is no association between the age of not gaining weight with weight achievements at 6 and 12 months. The frequency and subsequent events of not gaining weight of were consistently determining the growth of infant at 12 months of age. Child's morbidity was significantly associated with the event of 2 times and 3 times not gaining weight. It is recommended that infants who do not gain weight 2 times should have health examination for prompt treatment.
\end{abstract}

\section{PENDAHULUAN}

G angguan pertumbuhan merupakan salah satu masalah kesehatan utama pada anak di Indonesia. Pada tahun 2002, proporsi anak dengan berat badan menurut umur di bawah - 2 SD (yang selanjutnya disebut KEP) adalah sebesar 27.3\% (Depkes, 2003). Berbagai kajian telah dilakukan untuk menjelaskan permasalahan KEP di Indonesia. Jahari (2000) mempelajari sebaran prevalensi KEP menurut kelompok umur dari tahun 1989 sampai dengan 1999. Disimpulkan bahwa terjadi fluktuasi prevalensi KEP pada kelompok usia 6-23 bulan, yang menandakan bahwa kelompok 6-23 bulan lebih rentan dibandingkan kelompok usia lain. Dikemukakan bahwa pada usia 0 bulan, rata-rata berat badan anak mendekati median rujukan. Pada kelompok usia selanjutnya deviasi status berat anak dari rujukan. Kajian tersebut sejalan dengan temuan Jus'at (1991), Shrimpton (2001), Smicht (2002) dan Maleta (2003).

Kurang Energi Protein tidak terjadi secara tiba-tiba (akut), tetapi merupakan kejadian kronis, yang ditandai dengan kenaikan berat badan yang tidak cukup. Perubahan berat badan merupakan indikator yang dianggap sensitif untuk mendeteksi perubahan keadaan gizi masyarakat.

Pemantauan pertumbuhan merupakan suatu rangkaian kegiatan yang terdiri pengukuran pertumbuhan fisik dan perkembangan individu di masyarakat dengan tujuan meningkatkan status kesehatan anak, perkembangan dan kualitas 
hidup. Pemantauan pertumbuhan terdiri 4 kegiatan utama, yaitu; (1) Penilaian (assessement) pertumbuhan anak secara teratur (terdiri dari penimbangan setiap bulan, pengisian Kartu Menuju Sehat (KMS), menentukan status pertumbuhan berdasarkan kenaikan berat badan); (2) menindak lanjuti setiap kasus gangguan pertumbuhan (biasanya berupa konseling dan rujukan); (3) menindak lanjuti berupa kebijakan dan program di tingkat masyarakat, serta meningkatkan motivasi untuk memberdayakan keluarga, dan; (4) melakukan pemantauan, evaluasi serta tindak lanjut. (Rohde, 1964; Griffiths, 1996; Hall, 2000)

Masalah-masalah di dalam pelaksanaan pemantauan pertumbuhan telah dikenali sejak tahun 1980-an (Rohde, 1988; UNICEF, 1990). Garner, dkk (2000) melakukan systematic review berdasarkan cochrane controlled trials register, World Health Organization dan World Bank publications. Dengan inklusi kriteria desain eksperimen dan kuasi eksperimen ditemukan 2 penelitian yang memenuhi inklusi kriteria. Penelitian Wright (1998) menyimpulkan bahwa pemantauan pertumbuhan yang diikuti dengan intervensi kunjungan petugas kesehatan berpengaruh bermakna tarhadap status gizi anak. Pada kelompok yang menderita gagal tumbuh, sebanyak $76 \%$ anak pada kelompok intervensi sembuh, dibandingkan $55 \%$ pada kelompok kontrol. Dengan desain yang sama Raynor dkk (1998), menemukan tidak adanya perbedaan bermakna antara kelompok perlakuan dan kelompok kontrol.

Dari uraian tersebut diatas dapat disimpulkan bahwa efektivitas dan efisiensi pemantauan pertumbuhan ditentukan oleh pengukuran pertumbuhan yang tepat dan tindak lanjut yang cepat dan tepat. Untuk dapat menentukan tindak lanjut yang cepat dan tepat diperlukan informasi penyebab gangguan pertumbuhan. Penelitian ini dilakukan diharapkan dapat menjawab masalah tersebut.
Tujuan

Tujuan umum penelitian adalah mempelajari hubungan pola perubahan berat badan dengan pertumbuhan bayi 6-12 bulan.

Tujuan khusus penelitian adalah sebagai berikut:

a. Menguji hubungan frekuensi dan kontinyuitas berat badan tidak naik dengan kenaikan berat badan bayi usia 6-12 bulan.

b. Menguji hubungan frekuensi dan kontinyuitas berat badan tidak naik dengan berat badan bayi usia 12 bulan.

c. Menguji hubungan berat badan dan panjang badan 6 bulan dengan kenaikan berat badan bayi usia 6-12 bulan dan berat badan bayi pada usia 12 bulan.

d. Mempelajari faktor yang berhubungan dengan kenaikan berat badan bayi 6 12 bulan.

\section{BAHAN DAN CARA}

\section{Rancangan penelitian}

Penelitian ini bersifat observasional dengan rancangan kohor prospektif, yaitu memantau secara berkala bayi sejak usia 6 bulan sampai 12 bulan. Pemilihan subyek penelitian dilakukan melalui langkah-langkah sebagai berikut;

1) Registrasi bayi usia 5, 6 bulan untuk menjaring bayi usia 6 bulan.

2) Setiap bayi berusia 6 bulan dilakukan pemeriksaan kesehatan dan antropometri untuk menentukan apakah bayi memenuhi kriteria inklusi.

3) Bayi yang memenuhi kriteria inklusi, orang tuanya (ayah/ibu) diberi penjelasan dan diminta persetujuaannya mengikuti penelitian. Orang tua yang tidak berkeberatan diminta menandatangai formulir persetujuan mengikuti penelitian. 


\section{Populasi dan sampel}

Populasi penelitian adalah bayi usia 612 bulan. Subyek penelitian adalah bayi yang memenuhi kriteria inklusi: Berusia 6 bulan, tidak menderita cacat bawaan dan penyakit kronis, bayi dengan berat lahir diatas 2500 gram, bertempat tinggal di lokasi posyandu terpilih dan bersedia ikut penelitian. Semua subyek yang memenuhi kriteria inklusi diikutkan di dalam penelitian sampai memenuhi kebutuhan minimum subyek.

Besar sampel dihitung berdasarkan rumus hypothesis test for an incidence rate, two-sided test (Lwanga, 1990). Dengan asumsi insidens gagal tumbuh di wilayah penelitian (sebesar 20\%), batas kepercayaan á $=0.05$, dan dengan perkiraan mengundurkan diri maksimum sebesar $20 \%$ diperoleh besar sampel masing-masing 196 anak.

\section{Pengumpulan dan pengolahan data}

Data berat badan dan panjang badan dikumpulkan melalui pengukuran setiap bulan. Data kesakitan, pola konsumsi makanan, sosial ekonomi keluarga dikumpulkan melalui wawancara oleh 10 petugas pewawancara terlatih.

Analisis dilakukan secara bertahap sebagai berikut:
1. Re-coding data berat badan untuk menentukan status pertumbuhan setiap anak

2. Analsis deskriptif, untuk melihat karakteristik responden, termasuk melihat frekuensi, distribusi dan mencari hubungan setiap variabel bebas dan variabel tergantung.

3. Analisis multivariat, untuk mencari faktor yang mempengaruhi pertumbuhan.

Data entry dan cleaning dilakukan dengan foxpro, sedangkan analisis lanjut mempergunakan Stata Ver 7.0.

\section{HASIL}

\section{Pertumbuhan bayi 6-12 bulan}

Gambar 1 menyajikan Z_Score BB/U, PB/U dan BB/PB subyek. Kurva Z_Score BB/ $U$ bayi 6-12 bulan menunjukkan lebih berfluktuasi. Pada usia usia 6 bulan, kurva Z_Score BB/U berada diatas PB/U. Pada usia 7-9 bulan mulai terjadi penurunan Z_Score BB/U, lebih rendah dibandingkan dengan sebelumnya $(p<0.05)$. Pada usia 912 bulan, perubahan Z_Score BB/U setiap bulan tidak berbeda $(p>0.05)$. Penurunan Z_Score BB/U pada usia 7-9 bulan, dan tidak adanya perubahan Z_Score PB/U pada periode yang sama menyebabkan kurva $\mathrm{BB} /$ U memotong kurva PB/U pada usia tersebut. Pada usia 12 bulan Z_Score BB/U lebih rendah dibandingkan dengan $Z$ _Score PB/U. 


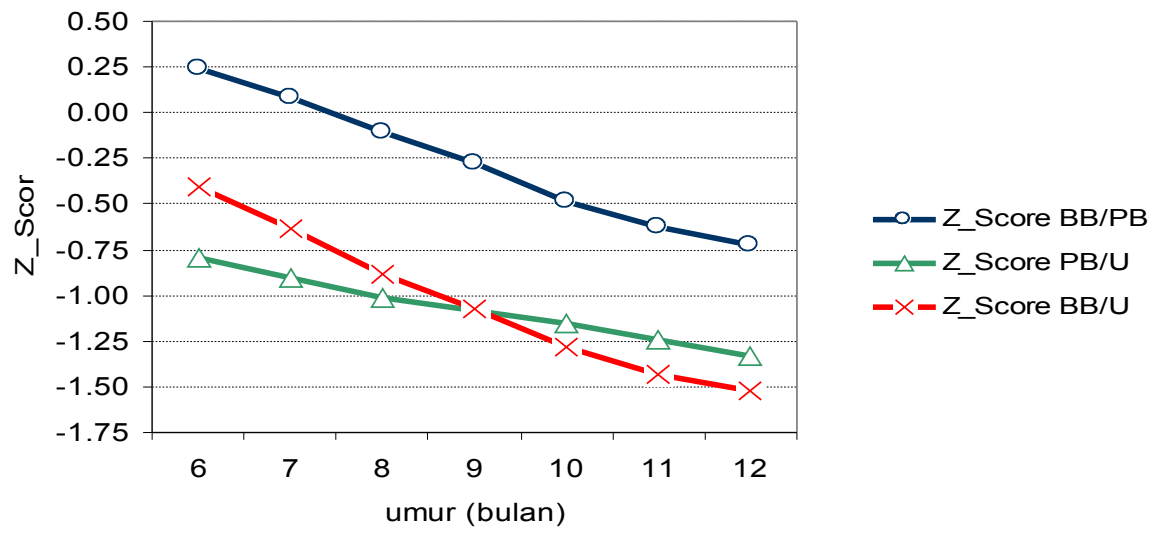

Gambar 1

Kecenderungan Z-Score BB/U, PB/U dan BB/PB bayi 0-12 bulan

Terdapat perbedaan penurunan Z_Score BB/U bermakna pada usia 8-9 bulan, 10-11 bulan dan 11-12 bulan $(p<0.05)$. Terdapat perbedaan penurunan $Z$ _Score PB/U bermakna pada usia $6-7$ bulan $(p<0.05)$. Perubahan Z_Score BB/PB dan Z_Score PB/U pada usia 7-8, 8-9, 9-10, 10-11, 11-12 bulan tidak berbeda ( $p>0.05)$.

Untuk mengetahui besarnya gangguan pertumbuhan bayi 6-12 bulan dilihat berdasarkan perbedaan Z_Score BB/U, TB/ $\mathrm{U}$ dan BB/TB bayi pada usia 6 bulan dengan bayi usia 12 bulan. Pada table 1 dapat dilihat bahwa Z_Score BB/U, PB/U, BB/PB bayi usia 12 bulan lebih rendah bermakna $(p<0.01)$ dibandingkan usia 6 bulan.
Z_Score BB/U 12 bulan turun sekitar 1.123 dibandingkan Z_Score BB/U 6 bulan. Sementara itu Z_Score PB/U 12 bulan 0.537 lebih rendah dibanding usia 6 bulan $(p<0.01)$. Z_Score PB/U usia 6 bulan -0.795 turun menjadi -1.331 pada usia 12 bulan. Penurunan Z_Score BB/U hampir dua kali lipat penurunan Z_Score PB/U.

Tabel 1

Perbedaan rata-rata Z_Score PB/U, BB/U, BB/PB 6 bulan dengan Z_Score PB/U, BB/U, BB/PB 12 bulan

\begin{tabular}{|l|c|c|c|c|}
\hline & $\begin{array}{c}6 \text { bulan } \\
(1)\end{array}$ & $\begin{array}{c}12 \text { bulan } \\
(2)\end{array}$ & $\begin{array}{c}\text { Perbedaan rata-rata } \\
(2-1)\end{array}$ & Sig \\
\hline BB/U & -0.402 & -1.525 & $-1.123^{*}$ & 0.000 \\
PB/U & -0.795 & -1.331 & $-0.537^{*}$ & 0.000 \\
BB/PB & 0.245 & -0.724 & $-0.969^{*}$ & 0.000 \\
\hline
\end{tabular}

Perbedaan bermakna pada $p<0.01$

Untuk mengetahui lebih jauh masalah gangguan pertumbuhan, dilakukan analisis pencapaian berat badan dan panjang badan, dibandingkan dengan rujukan NCHS 1977 dan WHO 2006 (gambar 2 dan 3). Deviasi pertumbuhan berat badan subyek dari rujukan sangat nyata. Pada usia 6 bulan, perbedaan berat badan bayi dari rujukan 0.9 $\mathrm{Kg}$, sedangkan pada usia 12 bulan defisit berat badan mencapai $1.3 \mathrm{Kg}$. 


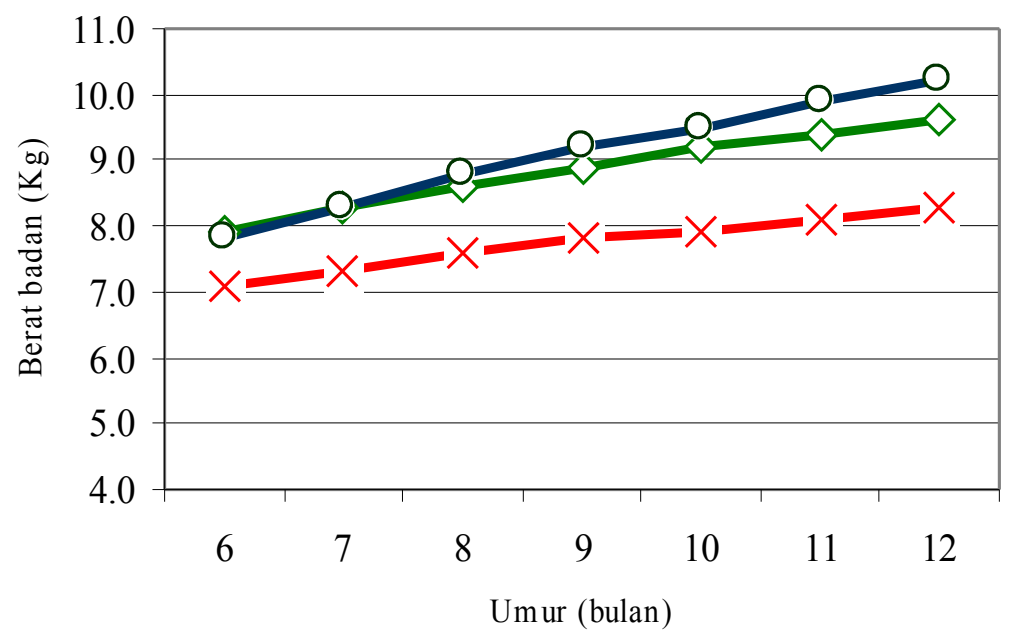

-X- Median Subyek $\leadsto$ Median Laki-laki WHO 2006

- Median Laki-laki NCHS 1977

Gambar 2

Perbandingan berat badan subyek dengan rujukan NCHS-1977 dan WHO-2006

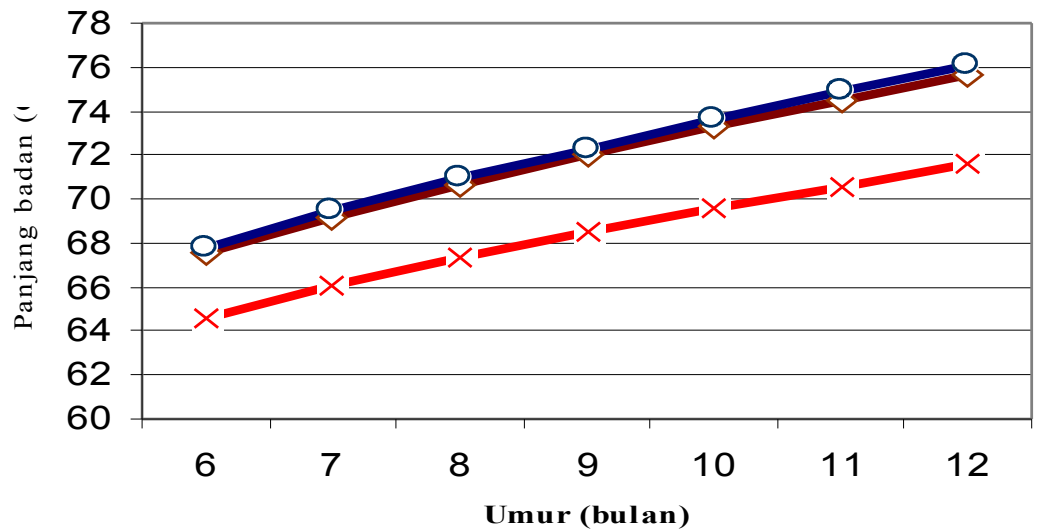

- $\times=$ Median Subyek

$\leadsto$ Median Laki-laki WHO 2006

- Median Laki-laki NCHS 1977

Gambar 3

Perbandingan berat badan subyek dengan rujukan NCHS-1977 dan WHO-2006 
Kecenderungan yang sama terjadi pada pertumbuhan panjang badan. Pada usia 6 bulan, median panjang badan subyek 3.1 $\mathrm{Cm}$ lebih rendah dari rujukan, pada usia 12 bulan perbedaan panjang badan subyek terhadap rujukan menjadi $4.1 \mathrm{Cm}$.

\section{Frekuensi berat badan tidak naik}

Sebaran subyek berdasarkan frekuensi berat badan tidak naik dan perbedaan kenaikan berat badan $6-12$ bulan, berat badan usia 12 bulan menurut frekuensi berat badan tidak naik disajikan pada tabel 2 . Terdapat 9 subyek $(9.6 \%)$ berat badannya naik terus selama 6 bulan. Subyek dengan berat badan tidak naik 1 kali, 2 kali dan kali masing-masing $28.3 \%$, 35.6\% dan $26.5 \%$. Subyek yang berat badannya tidak naik 2 kali berturut-turut $35.6 \%$, sedangkan yang tidak naik 3 kali berturut-turut $7.8 \%$.

Tabel 2

Sebaran subyek berdasarkan frekuensi berat badan tidak naik

\begin{tabular}{|c|c|c|c|c|c|c|c|}
\hline \multirow[t]{2}{*}{ Frekuensi berat badan tidak naik } & \multirow{2}{*}{$\begin{array}{c}\% \\
(n=219)\end{array}$} & \multicolumn{3}{|c|}{$\begin{array}{c}\text { Kenaikan Z_Score BB/U 6- } \\
12 \text { bulan }\end{array}$} & \multicolumn{3}{|c|}{ Z_Score BB/U 12 bulan } \\
\hline & & Median & SD & Sig & Median & SD & Sig \\
\hline \multicolumn{8}{|l|}{ Frekuensi BB TN } \\
\hline TN 0 kali & 13.2 & -0.531 & 0.277 & 0.000 & -0.914 & 0.856 & 0.000 \\
\hline TN 1 kali & 24.7 & -0.758 & 0.333 & & -1.355 & 0.816 & \\
\hline TN 2 kali & 35.6 & -1.193 & 0.312 & & -1.537 & 0.777 & \\
\hline TN 3 kali & 26.5 & -1.634 & 0.410 & & -1.972 & 0.824 & \\
\hline \multicolumn{8}{|l|}{ BB TN 2 kali berturut-turut } \\
\hline Tidak & 64.4 & -0.966 & 0.465 & 0.000 & -1.443 & 0.898 & 0.063 \\
\hline Ya & 35.6 & -1.406 & 0.463 & & -1.671 & 0.799 & \\
\hline \multicolumn{8}{|l|}{ BB TN 3 kali berturut-turut } \\
\hline Tidak & 92.2 & -1.064 & 0.467 & 0.000 & -1.480 & 0.870 & 0.009 \\
\hline Ya & 7.8 & -1.830 & 0.465 & & -2.051 & 0.683 & \\
\hline
\end{tabular}

Subyek yang berat badannya naik terus mempunyai kenaikan Z_Score BB/U -0.531 , sedangkan yang tidak naik 3 kali -1.634 . Demikian pula dengan berat badan usia 12 bulan. Subyek yang berat badannya naik terus mempunyai Z_Score BB/U usia 12 bulan -0.914 , pada subyek yang tidak naik 3 kali -1.972 . Terdapat hasil yang konsisten, semakin sering berat badan tidak naik, kenaikan berat badan 6-12 bulan dan berat badan 12 bulan semakin kecil $(p<0.01)$.

\section{Hubungan frekuensi berat badan tidak naik dengan kenaikan berat badan 6-12 bulan dan berat badan usia 12 bulan}

Untuk mengetahui pengaruh frekuensi berat badan naik terhadap kenaikan berat badan 6-12 bulan dan berat badan usia 12 bulan dilakukan dengan analisis regresi ganda, dengan menempatkan kenaikan berat badan $6-12$ bulan dan berat badan 12 bulan sebagai variabel tergantung. Variabel frekuensi berat badan tidak naik (dummy), dan variabel morbiditas, pola konsumsi makan, sosial ekonomi diperlakukan sebagai variabel bebas. Kenaikan berat badan bayi 6-12 bulan dan berat badan bayi usia 12 bulan dipengaruhi oleh berat badan bayi usia 6 bulan, morbiditas, pola konsumsi makanan, frekuensi berat badan tidak naik dan frekuensi tidak naik 2 kali berturut-turut. Model prediksi kenaikan berat badan 6-12 bulan dan berat badan 12 bulan sebagai berikut; 
Model 1: Faktor yang mempengaruhi kenaikan berat badan bayi 6-12 bulan

$\begin{aligned} \text { Kenaikan BB } 6-12=-1.298- & 0.102 \mathrm{bbObln}-0.080 \text { frekbatuk }-0.141 \text { makbayi }+0.174 \text { tn2kalicont } \\ & +1.153 \text { tnOkali }+0.949 \text { tn } 1 \text { kali }+0.488 \text { tn2kali }\end{aligned}$

Model 2: Faktor yang mempengaruhi berat badan prediksi berat badan bayi 12 bulan

BB 12 bulan $=-1.489+0.901$ bb6bln -0.197 lamaskt +0.161 makbayi +1.137 tnOkali + 0.937 tn1 kali +0.482 tn2kali +0.173 tn2kalitrt

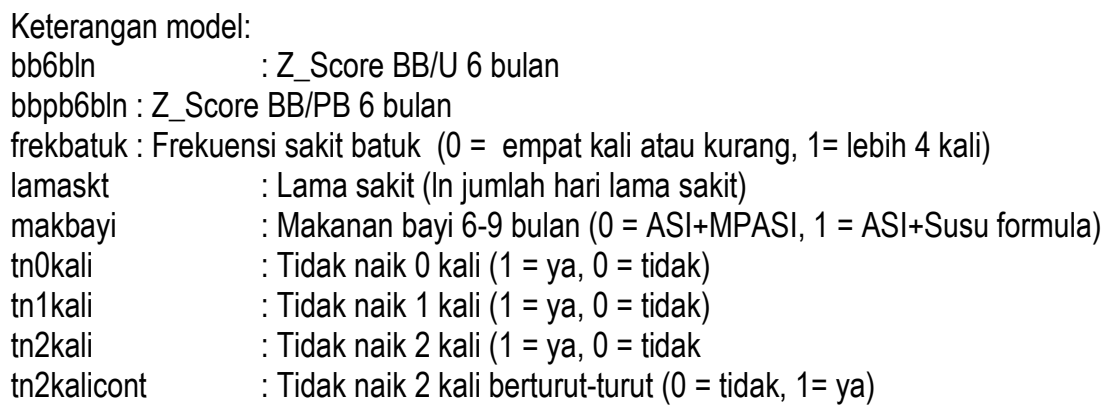

Model 1 tersebut cukup baik, dapat menjelaskan $62.5 \%$ kejadian kenaikan berat badan bayi $6-12$ bulan. Berat badan tidak naik memberikan kontribusi terbesar terhadap kenaikan berat badan bayi 6-12 bulan. Terdapat hubungan negatif antara $\mathrm{BB} /$ U 6 bulan dengan kenaikan BB/U 6-12 bulan. Semakin besar BB/U 6 bulan kenaikan berat badan $6-12$ bulan semakin kecil. Frekuensi berat badan tidak naik 2 kali berturut-turut, juga berkontribusi bermakna terhadap kenaikan BB/U 6-12 bulan. Kenaikan BB/U 6-12 bulan bayi yang berat badannya pernah tidak naik 2 kali berturut-turut 0.174 lebih rendah dibandingkan yang tidak. Variabel frekuensi batuk selama 6 bulan dan makanan bayi juga berpengaruh terhadap kenaikan BB/U 6-12 bulan. Dengan mengendalikan faktor-faktor lain, perbedaan kenaikan berat badan antara bayi yang berat badannya naik terus dan tidak naik 3 kali 1.153 , antara yang naik terus dan tidak naik 2 kali 0.665 , antara yang naik terus dan tidak naik 1 kali 0.204 .

Model 2 sangat baik, mampu menjelaskan 86.6 \% Z_Score BB/U bayi 12 bulan. Variabel BB/U 6 bulan mempunyai kontribusi terbesar terhadap BB/U 12 bulan. Setiap kenaikan 1 unit SD BB/U 6 bulan akan meningkatkan BB/U 12 bulan sebesar 0.901 unit SD. Variabel lama sakit berpengaruh negatif terhadap BB/U 12 bulan. Perbedaan Z_Score BB/U 12 bulan bayi yang berat badannya naik terus dengan tidak naik 3 kali, tidak naik 2 kali dan tidak naik 1 kali masing-masing 1.137, 0.937 dan 0.482 .

\section{Faktor yang mempengaruhi frekuensi berat badan tidak naik}

Untuk mengetahui faktor-faktor yang mempengaruhi frekuensi berat badan tidak naik dilakukan analisis regresi logistik. Frekuensi dan kontinyuitas berat badan tidak naik sebagai variabel tergantung dikelompokkan sebagai berikut; (0) Berat badan naik terus; (1) tidak naik 1 kali; (2) tidak naik 2 kali berturut-turut; dan (3) tidak naik 3 kali berturut-turut.

Terdapat perbedaan faktor yang mempengaruhi berat badan naik terus, tidak naik 1 kali, tidak naik 2 kali berturut-turut dan 
tidak naik 3 kali berturut-turut. Pola makanan bayi berperan sebagai faktor risiko pada berat badan naik terus dan tidak naik sampai dua kali $(p<0.05)$. Risiko relatif berat badan naik terus pada bayi yang diberi ASI+MPASI $0.306(95 \% \mathrm{Cl}$ 0.118-0.797) dibandingkan dengan bayi yang diberi ASI+Susu Formula.

Peranan morbiditas terutama lama batuk mempengaruhi frekuensi berat badan tidak naik. Risiko tidak naik 2 kali berturutturut bayi yang sakit batuk lebih dari 14 hari 2.169 kali $(95 \% \quad \mathrm{Cl} \quad 1.197-3.930)$ dibandingkan dengan bayi yang pernah sakit batuk kurang dari 15 hari. Bila lama sakit lebih dari 28 hari, risiko untuk tidak naik 3 kali berturut-turut 4.804 kali $(95 \% \mathrm{Cl} 1.472-$ 15.678). Model faktor yang mempengaruhi frekuensi berat badan tidak naik disajikan pada lampiran.

\section{BAHASAN}

Penggunaan berat badan tidak naik untuk menentukan status pertumbuhan bayi sudah sangat meluas, tetapi belum ada kesepakatan tentang kriteria tentang gagal tumbuh, baik batasan ambang batas yang dipakai maupun frekuensi berat badan tidak naik yang menggambarkan gangguan pertumbuhan serta tindak lanjut terhadap hasil pemantauan. Salah satu pedoman yang dapat dipakai adalah bila grafik berat badan bayi dalam KMS menyeberang lebih dari 1 persentil pada baku rujukan (WHO, 1978), atau apabila kenaikan berat badan lebih rendah dari kenaikan pada persentil ke 5 rujukan (Eurogrowth, 2000).

Perbedaan kenaikan berat badan dan berat badan pada bayi 6 bulan dan bayi 12 bulan dilakukan dengan pendekatan matematis (model 1 dan model 2) disajikan pada tabel 3 berikut. 
Tabel 3

Pengaruh frekuensi berat badan tidak naik terhadap kenaikan berat badan bayi 6 bulan dan 12 bulan

\begin{tabular}{|l|r|r}
\hline $\begin{array}{l}\text { Perbedaan antar frekuensi berat badan } \\
\text { tidak naik }\end{array}$ & $\begin{array}{l}\text { Kenaikan BB } \\
\text { 6-12 bulan }\end{array}$ & BB 12 bulan \\
\hline TN 0 kali dan TN 1 kali & 200 & 200 \\
TN 0 kali dan TN 2 kali & 900 & 650 \\
TN 0 kali dan TN 3 kali & 1150 & 1050 \\
TN 1 kali dan TN 2 kali & 450 & 450 \\
TN 2 kali dan TN 3 kali & 400 & 400 \\
TN 2 kali berturut-turut dan tidak berturut- & 150 & 100 \\
turut & & \\
\hline
\end{tabular}

TN = Tidak naik

Analisis multivariat menunjukkan hasil yang konsisten. Semakin sering berat badan tidak naik, kenaikan berat badan bayi 6-12 bulan dan berat badan uisa 12 bulan semakin kecil. Perbedaan Z_Score BB/U 12 bulan antara bayi yang berat badannya naik terus dengan yang tidak naik 3 kali 1.137 unit SD (1050 gram), antara berat badan naik terus dengan tidak naik 2 kali 0.665 unit SD atau setara dengan 650 gram. Kontinyuitas berat badan tidak naik juga berpengaruh terhadap kenaikan berat badan bayi 6-12 bulan dan berat badan bayi 12 bulan. Bayi dengan berat badan tidak naik 2 kali berturut-turut mempunyai Z_score BB/U 12 bulan 0.173 (setara dengan 100 gram) lebih rendah dibandingkan bayi yang tidak naik 2 kali tidak berturut-turut.

Pengaruh morbiditas terhadap pertumbuhan dan status gizi bayi telah banyak di teliti. Berbagai penyakit yang telah dibuktikan berpengaruh terhadap pertumbuhan bayi adalah diare (Brown, 2003; Rowland, 1997; Black, 1984; Victora, 1990, dan Alan, 2000). Diare (jenis, frekuensi dan lama) terbukti perbengaruh terhadap pertumbuhan berat dan panjang badan bayi. Martorrel (1980) menemukan bahwa anak dengan infeksi saluran pernafasan akut dan diare asupan energinya masing-masing $8 \%$ dan $18 \%$ lebih rendah dibandingkan dengan anak tanpa infeksi. Semakin berat infeksi, defisit energi semakin besar. Selama infeksi campak akut, anak- anak mengkonsumsi $75 \%$ energi lebih rendah dibandingkan setelah sembuh (Duggan, 1986). Scrimshaw (2003) mengungkapkan bahwa seorang anak yang menderita batuk (whooping cough) memerlukan waktu 39 minggu untuk mencapai berat badan sebelum sakit. Dilaporkan bahwa lebih dari $25 \%$ kasus yang 200 diamati memerlukan waktu lebih dari 25 650 minggu.

1050 Penelitian ini membuktikan diantara 450 variabel morbiditas yang dikumpulkan, lama 400 batuk merupakan variabel yang 100 mempengaruhi frekuensi berat badan tidak naik. Pada bayi dengan berat badan naik terus dan tidak naik 1 kali, peranan kesakitan belum terlihat bermakna. Berat badan naik terus dan tidak naik 1 kali lebih dipengaruhi faktor makanan bayi. Pada bayi yang berat badannya tidak 2 kali berturut-turut, variabel lama menderita batuk terlihat berperan nyata. Risko untuk berat badannya tidak naik 2 kali pada bayi yang menderita batuk lebih dari 14 hari 2.169 kali dibandingkan dengan yang sakit batuk kurang dari 14 hari. Risiko untuk tidak naik 3 kali berturut-turut bayi yang menderita batuk lebih dari 28 hari 4.80 kali dibandingkan yang sakit kurang dari 28 hari.

Penelitian tentang MPASI di 6 Propinsi (UNICEF, 1997) membuktikan bahwa MPASI yang diberikan kepada bayi 6-8 bulan bervariasi antara 146-267 kcal/hari dan antara 208-364 kcal/hari pada bayi 9-11 bulan. Dibandingkan dengan yang dianjurkan (recomended), defisit energi rata-rata pada bayi $6-8$ bulan $50 \mathrm{kcal} /$ hari, dan pada bayi 9 11 bulan $140 \mathrm{kcal} / \mathrm{hari}$.

Penelitian ini membuktikan bahwa pola makanan bayi berpengaruh terhadap berat badan bayi $6-12$ bulan maupun terhadap frekuensi berat badan tidak naik. Risiko relatif berat badan naik terus, tidak 1 kali dan tidak naik 2 kali bayi yang diberi ASI+MPASI masing-masing $0.306,0.296$ dan 0.234 . Pemberian ASI+MPASI merupakan faktor yang dapat mencegah berat badan tidak naik.

Shrimpton (2002) melakukan penelitian ekologis di Mozambigue, dengan tujuan mencari hubungan antara berbagai variabel 
antropometri terhadap berat lahir. Studi membuktikan bahwa berat lahir mempunyai korelasi dengan pertumbuhan berat badan bayi ( $r=0.805, p<0.01)$, berhubungan dengan panjang badan bayi $(r=0.837, p<0.01)$. Blair (2000) menemukan adanya korelasi negatif antara berat badan 0 bulan dengan kenaikan berat badan bayi $0-12$ bulan. Bayi 0 bulan dengan berat badan dibawah persentil 16 mempunyai kenaikan berat badan lebih besar dibandingkan dengan kenaikan berat badan bayi yang berat badan 0 bulan diatas persentil 16.

Penelitian ini menemukan bahwa berat badan 6 bulan berpengaruh sangat kuat terhadap berat badan 12 bulan. kuat. Setiap kenaikan 1 Z_Score BB/U 6 bulan, Z_Score $\mathrm{BB} / \mathrm{U} 12$ bulan akan meningkat sebesar 0.901 .

\section{KESIMPULAN}

Bayi 6-12 bulan mengalami 2 bentuk gangguan pertumbuhan yang serius. Pertama, terjadi penurunan kecepatan pertumbuhan panjang badan antara usia 612 bulan. Kedua, gangguan penurunan berat badan yang serius, yang lebih besar dibandingkan penurunan panjang badan. Frekuensi dan kontinyuitas berat badan tidak naik secara konsisten berpengaruh pada pertumbuhan bayi. Semakin sering berat badan tidak naik, kenaikan berat badan dan berat badan bayi $6-12$ bulan dan berat badan bayi 12 bulan semakin rendah.

Faktor-faktor yang mempengaruhi frekuensi berat badan tidak naik dan berat badan bayi usia 12 bulan adalah berat badan bayi 6 bulan, pola makanan bayi, lama bayi menderita batuk merupakan faktor risiko yang mempengaruhi frekuensi berat badan tidak naik. Pengaruh lama batuk mulai berperan bermakna pada bayi yang berat badannya tidak naik 2 kali. Semakin lama menderita batuk risiko berat badan tidak naik semakin besar.

Berdasarkan temuan tersebut penelitian merekomendasikan hal-hal sebagai berikut. (1). Bayi 6-12 bulan yang berat badannya tidak naik 2 kali perlu dilakukan pemeriksanaan untuk mendapatkan pemeriksaan lebih lanjut; (2). Penelitian ini sangat jelas menunjukkan bahwa pertumbuhan bayi 6-12 bulan dipengaruhi oleh berat badan dan panjang badan 6 bulan sebagai cerminan pertumbuhan prenatal. Oleh karena itu program gizi ke depan perlu memberi perhatian yang sungguh-sungguh kepada peningkatan gizi ibu hamil, bahkan pra hamil; dan (3). Praktik pemberian MPASI pada bayi 6-12 bulan hanya dapat mempertahankan pertumbuhan bayi sampai 8 bulan. Setelah usia 8 bulan MPASI tidak dapat memenuhi kebutuhan gizi bayi. Perlu kebijakan peningkatan MPASI yang komprehensif.

\section{RUJUKAN}

1. Achadi E L. (2002). Evaluation of Posyandu Revitalization. Center for Health Research, University of Indonesia

2. Alan D S, Marks G C, Baqui A H, Yunus $M$ and Fuchs G J. (2000). Association between clinical type of diarrhoea and growth of children under 5 years in rural Bangladesh. International Journal of Epidemiology, 29, 916-921

3. Arifeen S E, et al. (2000). Infant growth patterns in the slums of Dhaka in relation to the birth weight, intrauterine growth retardation, and prematurity. American Journal of Clinical Nutrition, 72,1010-1017

4. Black M M and Krishnakumar A. (1999). Predicting Longitudinal Growth Curves of Height and Weight Using Ecological Factors Children with and without Early Growth Deficiency. Journal of Nutrition, 129, 539-543

5. Black R. E., Brown K. H., Becker S. (1984). Effects of diarrhea associated with specific enteropathogens on the growth of children in rural Bangladesh. Pediatrics, 73, 799-805.[Abstract]

6. Blair P S, et al. (2000). Weight gain and sudden infant death syndrome: Change 
in weight z_score may identify infants at increased risk. Arch Dis Child, 82, 462469 (June)

7. Brown K H. (2003). Diarrhea and Malnutrition. J. Nutr., 133, 328S-332S

8. Cauldfield L E, Huffman S L, Piwoz E G. (1999). Interventions to improve intake of complementary food by infants 6 to 12 months of age in developing countries: Impacts on growth and on the prevalence of malnutrition and potential contribution to child survival. Food and Nutrition Bulletin, ,183, 20-2

9. Depkes. (2003). Gizi Dalam Angka. Depkes. Jakarta .

10. Griffiths M, Dickin K, Favin M. (1996). Promoting the Growth of Children: What Works. Rationale and Guidance for Programs. Human Development Departement. The World Bank.

11. Hall D M B. (200). Growth monitoring. Arch Dis Child, 82, 10-15

12. Hendrata L, Rohde J.(1988). Ten pitfalls of growth monitoring and promoion. Indian J Pediatr, 55, 9-15

13. Jahari A B. Status gizi balita sebelum dan selama krisis ekonomi. WKNPG VII. LIPI, 2000

14. Jus'at. (1991). Determinant of Nutritional Status of Prescholl Children in Indonesia: an analysis of the National Socio Economic Survey (SUSENAS 1987). Ph.D Thesis. Cornell University. New York.

15. Kusharisupeni. (1999). Peran berat lahir dan masa gestasi terhadap pertumbuhan linier bayi di Kecamatan Sliyeg dan Kecamatan Gabus Wetan, Kabupaten Indramayu, Jawa Barat. Disertasi. Universitas Indonesia

16. Li $H$, Stein A D, Barnhart $H X$, Ramakrishman and Reynaldo Martorrel. (2003). Associations between prenatal and postnatal growth and adult body size and consumption. AJCN, 77, 14981505
17. Lwanga SK and Lemeshow S (1990). Sample size determination in health studies: A practical manual. World Health Organization. Geneva.

18. Maleta K, Virtanen S, Espo M, Kulmata $T$ and Ashorn P. (2003). Timing of growth faltering in rural Malawi. Archives of Diseases in Childhood, 88, 574-578

19. Martorell R., Yarbrough C., Yarbrough S., Klein R. E. (1980). . The impact of ordinary illnesses on the dietary intakes of malnourished children. Am. J. Clin. Nutr. 33, 345-350.

20. Raynor P, Rudolf M C J, Cooper K, Marchant P, Cottrell D. (1999). A randomised controlled trial of specialist health visitor intervention for failure to thrive. Arch Dis Child, 80, 500-506 ( June )

21. Rowland M G, Cole T J, Whitehead R G. (1977). A quantitative study into the role of infection in determining nutritional status in Gambian village children. Br J Nutr 37(3), 441-50.

22. Schmidt M K, Muslimatun S, West C E, Schulting W, Gross R, Hautvast J G A J. (2002). Nutritional status and linear growth of Indonesian in West Java are determined more by prenatal environment than postnatal factors. The American Society for Nutritional Sciences J. Nutr, 132, 2202-2207

23. Scrimshaw N S. (2003). Historical Concepts of Interactions, Synergism and Antagonism between Nutrition and Infection. J. Nutr. 133, 316S-321S

24. Shrimpton R, Victora C G, Onis M, Lima R C, Blössner M, Clugston G. (2001). Worldwide Timing of Growth Faltering: Implications for Nutritional Interventions. PEDIATRICS, 107(5): e75

25. Shrimpton R. (2002). Growth monitoring in the context of life's cycle. Paper presented at the International Expert 
Seminar on Growth and Poverty. Jakarta

26. UNICEF (1977). 6 Sites Complementary Feeding Study. UNICEF, Jakarta

27. UNICEF (1998). The state of rhe world's children 1998. UNICEF.

28. Victora C. G., Barros F. C., Kirkwood B. R., Vaughan J. P. (1990). Pneumonia, diarrhea, and growth in the first $4 \mathrm{y}$ of lifea longitudinal study of 5914 urban Brazilian children. Am. J. Clin. Nutr.,52, 391-396.[Abstract]

29. Victora CG and Barros FC. (2001). The catch-up dilemma-relevance of Leitch's "low-high" pig to child growth in developing countries. International Journal of Epidemiology, 30, 217-220

30. WHO. (1995). Working Group on Infant Growth. An evaluation of infant growth: The use and interpretation of anthropometry in infant. Bull World Health Org, 73, 165-74.
31. WHO. (1978). A growth chart for international use in maternal and chikd care. WHO, Geneva

32. WHO. (2006). WHO Child Growth Standards. Length/height-for-age, weight-for-age, weight-for-length weight-for-height and body mass indexfor-age. WHO, Geneva.

33. Wilensky D, Ginsbrg G, Altman M, Tulchinsky $T$, Yishay $F$, Aurbach J. (1996). A community based study. Arch dis child, 75, 145-8

34. Wright C M. (2000). Identification and management of failure to thrive: a community perspective. Arch Dis Child, $82,5-9$ 
Lampiran 1

Model faktor yang mempengaruhi frekuensi berat badan tidak naik

\begin{tabular}{|c|c|c|c|c|c|c|c|c|}
\hline \multirow[t]{2}{*}{$\begin{array}{l}\text { Variabel berat badan } \\
\text { tidak naik }\end{array}$} & \multirow[t]{2}{*}{ Faktor risiko } & \multirow[t]{2}{*}{ B } & \multirow[t]{2}{*}{ S.E. } & \multirow[t]{2}{*}{ Wald } & \multirow[t]{2}{*}{ Sig. } & \multirow[t]{2}{*}{$\operatorname{Exp}(B)$} & \multicolumn{2}{|c|}{$95.0 \%$ C.I.for $\operatorname{Exp}(B)$} \\
\hline & & & & & & & Lower & Upper \\
\hline \multirow[t]{3}{*}{ BB TN 0 kali } & MAK9BL & -1.184 & 0.488 & 5.887 & 0.015 & 0.306 & 0.118 & 0.797 \\
\hline & PANAS06X & 0.643 & 0.347 & 3.436 & 0.064 & 1.903 & 0.964 & 3.757 \\
\hline & Constant & 1.621 & 0.583 & 7.741 & 0.005 & 5.060 & & \\
\hline \multirow[t]{3}{*}{ BB TN 1 kali } & MAK9BL & -1.217 & 0.393 & 9.614 & 0.002 & 0.296 & 0.137 & 0.639 \\
\hline & PANAS06X & 0.452 & 0.270 & 2.798 & 0.094 & 1.572 & 0.925 & 2.671 \\
\hline & Constant & 0.295 & 0.470 & 0.395 & 0.530 & 1.343 & & \\
\hline \multirow{6}{*}{$\begin{array}{l}\text { BB TN } 2 \text { kali } \\
\text { berturut-turut }\end{array}$} & MAK9BL & -1.452 & 0.477 & 9.275 & 0.002 & 0.234 & 0.092 & 0.596 \\
\hline & LMBTK14 & 0.774 & 0.303 & 6.522 & 0.011 & 2.169 & 1.197 & 3.930 \\
\hline & KELWAZOA & & & 6.087 & 0.048 & & & \\
\hline & KELWAZOA(1) & 0.930 & 0.423 & 4.839 & 0.028 & 2.535 & 1.107 & 5.805 \\
\hline & KELWAZOA(2) & 1.089 & 0.464 & 5.498 & 0.019 & 2.971 & 1.196 & 7.383 \\
\hline & Constant & -1.542 & 0.422 & 13.363 & 0.000 & 0.214 & & \\
\hline \multirow{5}{*}{$\begin{array}{l}\text { BB TN } 3 \text { kali } \\
\text { berturut-turut }\end{array}$} & LMBTUK28 & & & 9.143 & 0.01 & & & \\
\hline & LMBTUK28(1) & -0.294 & 0.853 & 0.119 & 0.730 & 0.745 & 0.140 & 3.965 \\
\hline & LMBTUK28(2) & 1.569 & 0.603 & 6.764 & 0.009 & 4.804 & 1.472 & 15.678 \\
\hline & MAK9BL & -0.584 & 0.796 & 0.537 & 0.464 & 0.558 & 0.117 & 2.657 \\
\hline & Constant & -2.990 & 0.466 & 41.111 & 0.000 & 0.050 & & \\
\hline
\end{tabular}

BB TN 0 kali

BB TN 1 kali

BB TN 2 kali berturut-turut

BB TN 3 kali berturut-turut

MAK9BL

PANAS06X

LMBTK28

BTUK14

KELWHZOA
Berat badan naik terus $(0=$ ya; $1=$ tidak)

Berat badan tidak naik 1 kali atau kurang ( $0=$ ya; $1=$ tidak $)$

Berat badan tidak naik 2 kali atau lebih atau lebih ( $0=$ tidak; $1=y a)$ Berat badan tidak naik 3 kali berturut-turut atau lebih $(0=$ tidak; $1=$ ya) Makanan bayi usia 9 bulan ( $0=\mathrm{ASI}+\mathrm{MPASI} ; 1=\mathrm{ASI}+$ Susu Formula) Frekuensi panas $\quad(0=$ Tidak pernah; $1=1-2 \mathrm{kali} ; 2=$ lebih 2 kali $)$ Lama batuk $\quad(0=<15$ hari; $1=15-28$ hari; $2=$ lebih 28 hari $)$ Lama batuk $\quad(0=<15$ kali; $1=$ diatas 15 hari $)$

Z_Score BB/PB 6 bulan $\quad(0=$ diatas median; $1=-1$ SD sd Median; 2 = dibawah $-1 \mathrm{SD}$ ) 